\title{
PENINGKATAN MOTIVASI DAN HASIL BELAJAR SISWA MELALUI PEMBELAJARAN DI LINGKUNGAN SEKOLAH PADA MATERI KEANEKARAGAMAN HAYATI DI KELAS X-MIA MAS AR-ROSYIDIYAH
}

\author{
Tuti Garnasih \\ MAS Ar-Rosyidiyah Kota Bandung \\ E-mail: tutigarnasih06@gmail.com
}

\begin{abstract}
The analysis result of student daily examination on biology study is still below the Minimum Criterion of Completeness (KKM).It indicate low motivation of students' learning on biology subject, due to the dominant application of teacher-centered learning. The purpose of this study was to improve motivation and learning outcomes of Biology X-MIA students in MAS Ar-Rosyidiyah Cibiru Bandung, on 2017/2018 school year. The subjects of this study were X-MIA class students as much as 34 students, on biodiversity topic.The results showed that the application of learning outside the classroom in the school zone can increase motivation and learning outcomes of X-MIA students on biology. Student learning motivation in cycle I was $72,24 \%$ increased by $85,50 \%$ in cycle II. The result of cognitive domain in cycle I was $82,35 \%$ to $88,23 \%$ in cycle II, whereas learning result of student affective aspect in cycle I was increasing from $82,29 \%$ to $85,15 \%$ in cycle II.
\end{abstract}

Keywords: Outdoor Learning, Learning Motivation, Learning Outcomes.

\begin{abstract}
Abstrak : Hasil analisis ulangan harian siswa pada mata pelajaran biologi masih berada di bawah Kriteria Ketuntasan Minimal (KKM) yang ditetapkan. Hal ini menunjukkan rendahnya motivasi belajar siswa pada mata pelajaran biologi akibat dominasi penerapan pembelajaran teacher-centered. Tujuan penelitian ini adalah untuk meningkatkan motivasi dan hasil belajar Biologi siswa kelas X-MIA di MAS Ar-Rosyidiyah Cibiru Kota Bandung tahun pelajaran 2017/2018. Subjek penelitian ini adalah siswa kelas X-MIA dengan jumlah siswa 34 orang, pada materi keanekaragaman hayati. Hasil penelitian menunjukkan bahwa penerapan pembelajaran di lingkungan sekolah dapat meningkatkan motivasi dan hasil belajar biologi siswa kelas X-MIA. Motivasi belajar siswa pada siklus I 72,24\% meningkat sebesar 85,50\% pada siklus II. Hasil belajar biologi ranah kognitif siswa pada siklus I 82,35\% menjadi 88,23\% pada siklus II sedangkan hasil belajar ranah afektif siswa pada siklus I $82,29 \%$ menjadi $85,15 \%$ pada siklus II.
\end{abstract}

Kata Kunci: Pembelajaran di luar ruangan, Motivasi Belajar, Hasil Belajar.

\section{PENDAHULUAN}

Biologi dapat menjadi pelajaran yang menakutkan kalau hanya berupa hafalan, tetapi biologi sangat menyenangkan apabila siswa rajin mengamati dan menghubungkan konsep biologi dengan kehidupan sehari-hari. Pembelajaran biologi menyangkut proses belajar yang berkaitan dengan makhluk hidup dan lingkungannya, suatu proses pembelajaran yang selalu berhubungan dengan aktivitas kehidupanan nyata. Materi keanekaragaman hayati membantu siswa dapat berperan aktif dengan lingkungan, siswa diberi pengalaman belajar yang memberikan kesempatan untuk membangun pemahamannya sendiri terhadap berbagai permasalahan lingkungan. Hasil kegiatan pembelajaran yang dihadapkan secara langsung pada permasalahan dapat mendorong atau memotivasi siswa untuk belajar.

Rendahnya hasil penilaian mata pelajaran biologi menunjukkan rendahnya motivasi belajar siswa karena pembelajaran biologi kurang menarik. Metode pembelajaran yang digunakan guru hanya menghafalkan suatu konsep sehingga siswa merasa bosan dan kurang berkonsentrasi dalam belajar. Siswa yang tuntas berdasarkan hasil analisis 


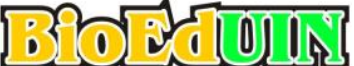

Jurnal Program Studi Pendidikan Biologi
p-ISSN : 2338-7173

e-ISSN : 2615-0417

(Februari), Vol. (8), No.(1) sebanyak tiga kali ulangan adalah $65 \%, 69 \%$, dan $68 \%$.

Berdasarkan permasalahan yang dialami siswa kelas x-mia mas ar-rosyidiyah tahun pelajaran2017/2018 diperlukan penerapan pembelajaran yang efektif untuk meningkatkan motivasi belajar sehingga hasil belajar siswa dalam kegiatan pembelajaran juga dapat ditingkatkan. Penerapan pembelajaran yang dilakukan diharapkan siswa tidak merasa merasa bosan dan jenuh dengan cara mengajar guru yang monoton, sehingga penulis menerapkan metode pembelajaran di luar ruangan kelas yaitu lingkungan sekolah sebagai alternatif pemecahan masalah pembelajaran di kelas. Pemanfaatan lingkungan merupakan pendekatan sosialisasi siswa terhadap obyek dan persoalan biologi di lingkungan, sehingga siswa mampu menyatu dengan lingkungan dan ekosistemnya (susanto, 2002). Pada hakikatnya siswa cenderung lebih senang berada diluar kelas daripada berada di dalam kelas untuk memperhatikan pelajaran yang diberikan.

Alasan yang dimungkinkan kenapa siswa senang pembelajaran di luar ruangan kelas karena siswa menggunakan media pembelajaran yang kongkrit dan memahami lingkungan yang ada disekitarnya. Guru masih menggunakan metode konvensional selama proses belajar mengajar, sehingga menyebabkan siswa tidak memperhatikan dan cenderung merasa bosan berada di dalam kelas untuk memperhatikan materi pelajaran yang diberikan.

Berdasarkan observasi dan identifikasi masalah yang telah diuraikan di atas, maka dilakukan penelitian dalam upaya meningkatkan motivasi dan hasil belajar siswa dengan judul Peningkatan Motivasi Dan Hasil Belajar Siswa Melalui Pembelajaran Di Lingkungan Sekolah Pada Materi Keanekaragaman Hayati Di Kelas X-Mia Mas Ar-Rosyidiyah.

\section{METODE}

Penelitian ini dilakukan melalui 2 siklus. Setiap siklus terdiri dari kegiatan perencanaan, pelaksanaan, observasi dan refleksi. Siklus I terdiri dari dua kali pertemuan, sedangkan siklus II terdiri dari tiga kali pertemuan yang setiap pertemuan diberi alokasi waktu $2 \times 45$ menit (2 jam pelajaran). Penelitian ini dilaksanakan di MAS Ar-Rosyidiyah Cibiru Kota Bandung tahun pelajaran 2017/2018 dengan subjek penelitian siswa kelas X-MIA yang berjumlah 34 siswa. Pendekatan penelitian yang digunakan adalah pendekatan deskriptif kualitatif dan termasuk ke dalam jenis Penelitian Tindakan Kelas (PTK) yang mengkaji tentang penerapan pembelajaran di kelas. Data pada penelitian ini berupa pernyataan yang diperoleh dari hasil wawancara, dokumentasi, observasi, dan catatan lapangan yang berkenaan dengan aktivitas siswa pada saat berlangsungnya kegiatan belajar mengajar berlangsung. Analisis data dalam penelitian ini, yaitu kegiatan observasi keterlaksanaan penerapan pembelajaran di lingkungan sekolah dihitung berdasarkan skor keterlaksanaan masing-masing tahap kegiatan, hasil observasi terhadap motivasi belajar siswa meliputi empat aspek, yaitu perhatian (Attention), keterkaitan (Relevance), kepercayaan diri (Confidence), dan kepuasan (Satisfaction) untuk tiap indikator, hasil belajar ranah kognitif dengan menggunakan soal tes akhir siklus dan hasil belajar ranah afektif dengan metode Linkert.

\section{HASIL}

\section{Data Keterlaksanaan Pembelajaran di Lingkungan Sekolah Data}

Data keterlaksanaan pembelajaran di lingkungan sekolah siklus I dan siklus II dapat dilihat seperti pada Tabel 1 berikut. Berdasarkan Tabel 4.1 dapat diketahui bahwa rata-rata persentase keterlaksanaan 


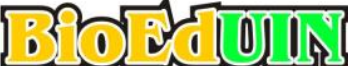

Jurnal Program Studi Pendidikan Biologi

pembelajaran di lingkungan sekolah pada siklus I adalah 91,7\% meningkat menjadi 100 \%pada siklus II. Persentase masing-masing tahaap pembelajaran, yaitu bahwa tahap awalsebesar $100 \%$ pada siklus I dan siklus II dengan taraf keterlaksanaan tindakan sangat
p-ISSN : 2338-7173

e-ISSN : 2615-0417

(Februari), Vol. (8), No.(1)

baik, tahap inti sebesar $83 \%$ pada siklus I meningkat menjadi $100 \%$ pada siklus II dengan taraf keterlaksanaan tindakan sangat baik, dan tahap akhir sebesar $100 \%$ pada siklus I dan siklus II dengan taraf keterlaksanaan tindakan sangat baik.

Tabel 1. Kriteria Keterlaksaan Pembelajaran di Lingkungan Sekolah Siklus I

\begin{tabular}{lccc}
\hline $\begin{array}{c}\text { Sintaks pembelajaran di } \\
\text { Luar Ruangan }\end{array}$ & $\begin{array}{c}\text { Keterlaksanaan } \\
\text { tindakan siklus I (\%) }\end{array}$ & $\begin{array}{c}\text { Keterlaksanaan } \\
\text { tindakan siklus II (\%) }\end{array}$ & $\begin{array}{c}\text { Taraf Keterlaksanaan } \\
\text { Tindakan }\end{array}$ \\
\hline Tahap Awal & 100 & 100 & Sangat baik \\
\hline Tahap Inti & 83 & 100 & Sangat baik \\
\hline Tahap Akhir & 100 & 100 & Sangat baik \\
\hline Rata-rata & $\mathbf{9 1 , 7}$ & $\mathbf{1 0 0}$ & Sangat baik \\
\hline
\end{tabular}

\section{Motivasi Belajar}

Berdasarkan Tabel 2. dapat diketahui bahwa rata-rata persentase motivasi siswa pada siklus I sebesar $72,24 \%$ menjadi $83,50 \%$ pada siklus II. Hal ini menunjukkan bahwa motivasi belajar siswa secara umum (klasikal) mengalami peningkatan sehingga motivasi siswa yang meliputi perhatian (Attention) dari siklus I sebesar $74,85 \%$ menjadi sebesar $84,55 \%$ pada siklus II, keterkaitan (Relevance) dari siklus I sebesar $71,76 \%$ menjadi sebesar
$83,3 \%$ dengan taraf pada siklus II, kepercayaan diri (Confidence) dari siklus I sebesar $71,47 \%$ menjadi sebesar $84,41 \%$ pada siklus II, dan Kepuasan (Satisfaction) dari siklus I sebesar 70,88\% menjadi sebesar $81,76 \%$ pada siklus II. Jika dibandingkan dengan siklus I maka persentase motivasi belajar siswa pada siklus II secara klasikal telah mengalami peningkatan sebesar $10,76 \%$. Perbandingan dapat dilihat motivasi belajar siswa secara klasikal antara siklus I dan siklus II pada Tabel 2. sebagai berikut.

Tabel 2. Motivasi Belajar Siswa pada Siklus I dan Siklus II

\begin{tabular}{lccc}
\hline \multicolumn{1}{c}{ Indikator Motivasi } & $\mathbf{M B K}_{\mathbf{I}}(\boldsymbol{\%})$ & $\mathbf{M B K}_{\mathbf{I I}}(\boldsymbol{\%})$ & Peningkatan (\%) \\
\hline Perhatian (Attention) & $74,85 \%$ & $84,55 \%$ & $9,7 \%$ \\
Keterkaitan (Relevance) & $71,76 \%$ & $83,3 \%$ & $11.54 \%$ \\
Kepercayaan diri (Confidence) & $71,47 \%$ & $84,41 \%$ & $12.94 \%$ \\
Kepuasan (Satisfaction) & $70,88 \%$ & $81,76 \%$ & $10.88 \%$ \\
\hline MBK & $\mathbf{7 2 , 2 4 \%}$ & $\mathbf{8 3 , 5 0 \%}$ & $\mathbf{1 1 , 2 6 \%}$ \\
\hline
\end{tabular}

Catatan: $\mathrm{MBK}_{\mathrm{I}}=$ Motivasi Belajar Klasikal Siklus I $\mathrm{MBK}_{\mathrm{II}}=$ Motivasi Belajar Klasikal Siklus II

\section{Hasil Belajar}

\section{Hasil Belajar Ranah Kognitif}




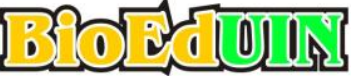

Jurnal Program Studi Pendidikan Biologi

Data hasil test siklus I akan dibandingkan dengan data hasil test pada siklus II. Data siklus I diperoleh dari rata-rata hasil test pada materi Dunia Tumbuhan (Plantae), sedangkan data siklus II diperoleh dari rata-rata hasil test pada materi Dunia Hewan (Animalia). Ketuntasan belajar individual yang telah ditetapkan di kelas X-MIA adalah $\geq 75 \%$, sedangkan ketuntasan klasikal adalah $\geq 85 \%$ dari jumlah seluruh siswa yang mencapai KKM. Siswa yang sudah mencapai KKM pada siklus I adalah 28 siswa jika dipersentasekan

\begin{tabular}{|l|c|c|}
\hline \multicolumn{1}{|c|}{ Hasil Test Biologi } & Siklus I & Siklus II \\
\hline Skor terendah & 56 & 68 \\
\hline Skor tertinggi & 90 & 96 \\
\hline THBK & $\mathbf{8 2 , 3 5 \%}$ & $\mathbf{8 8 , 2 3 \%}$ \\
\hline
\end{tabular}

dapat dilihat pada Tabel 3.

Tabel 3. Hasil Belajar Ranah Kognitif Siswa

Catatan: THBK = = Tes Hasil Belajar Kognitif

\section{Hasil Belajar Ranah Afektif}

Tes ranah afektif merupakan tes yang bertujuan untuk mengetahui sikap siswa setelah mempelajari materi pelajaran yang nantinya dapat diaplikasikan pada kehidupan sehari-hari. Data hasil belajar ranah afektif siswa pada siklus I dan II selengkapnya dapat dilihat pada Tabel 4. berikut. Berdasarkan Tabel 4. dapat diketahui bahwa nilai terendah untuk hasil belajar ranah afektif siklus I adalah 76, sedangkan nilai tertinggi adalah 88 . Presentase rata-rata hasil belajar afektif untuk siklus 1 sebesar $82,29 \%$. Nilai terendah untuk hasil belajar ranah afektif siklus II adalah 78, sedangkan nilai tertinggi adalah 89 . Presentase rata-rata hasil belajar afektif untuk siklus II meningkat menjadi $85,02 \%$. Hal ini
p-ISSN : 2338-7173

(Februari), Vol. (8), No.(1)

sebesar 82,35\% sehingga dapat dikatakan bahwa secara klasikal hasil belajar siswa tidak tuntas. Siklus II siswa yang mampu mencapai KKM yang telah ditetapkan berjumlah 30 siswa jika dipersentasekan sebesar 88,23\% sehingga dapat dikatakan bahwa secara klasikal hasil belajar siswa tuntas. Berdasarkan persentase ketuntasan belajar yang diperoleh pada siklus II, dapat dikatakan mengalami peningkatan sebesar 5,88\% dari persentase Siklus I. Perbandingan data hasil belajar ranah kognitif pada siklus I ke siklus I
e-ISSN : 2615-0417 


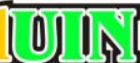

Jurnal Program Studi Pendidikan Biologi

berusaha memperbaiki kekurangan yang ada pada siklus I. Aktivitas pembelajaran pada

siklus II mengalami peningkatan sebesar $8,3 \%$. Siswa juga terlihat aktif dalam lingkungan sekolah masih ada siswa kurang konsentrasi selama proses pembelajaran karena suasana yang ramai sehingga siswa lebih melihat lingkungan sekitarnya. Selain itu guru juga kurang memperhatikan alokasi waktu terutama saat melakukan pengamatan. Guru sebaiknya juga memperhatikan Kompetensi Dasar (KD) yang digunakan dan sumber belajar yang tersedia di sekolah apabila melaksanakan pembelajaran di lingkungan sekolah agar semua materi dapat dipelajari siswa. Apabila di sekolah fasilitas tidak memadai dapat menggunakan fasilitas di luar sekolah dengan memperhitungkan biaya yang disediakan siswa ataupun sekolah.

Djamarah (2006) menjelaskan bahwa pembelajaran di lingkungan sekolah pastinya memiliki kekurangan diantaranya adalah memerlukan persiapan koordinasi yang matang, sulit mengatur siswa selama kegiatan berlangsung, siswa sering kurang konsentrasi karena berada di lingkungan yang terbuka, dan fasilitas serta biaya yang dipergunakan sulit disediakan oleh siswa atau sekolah.

\section{Hasil Belajar}

\section{Ranah Kognitif}

Untuk mengetahui tingkat pemahaman dan kemampuan siswa setelah diberikan pembelajaran di lingkungan sekolah maka diberikan test hasil belajar pada tiap siklus. Data hasil test siklus I akan dibandingkan dengan data hasil test pada siklus II. Data siklus I diperoleh dari rata-rata hasil test pada materi Dunia Tumbuhan (Plantae), sedangkan data siklus II diperoleh dari rata-rata hasil test pada materi Dunia Hewan (Animalia). Peningkatan skor rata-rata hasil belajar siswa dari siklus I ke siklus II dapat disebabkan adanya penerapan pembelajaran di lingkungan
p-ISSN : 2338-7173

e-ISSN : 2615-0417

(Februari), Vol. (8), No.(1)

mengikuti proses pembelajaran yang berlangsung baik diskusi dan presentasi. Selama pembelajaran di

sekolah. Pembelajaran di lingkungan sekolah merupakan pemebelajaran di mana guru mengajak siswa belajar di luar kelas untuk melihat peristiwa langsung di lapangan dengan tujuan untuk mengakrabkan siswa dengan lingkungan, sehingga siswa dapat mengkonstruk diri mereka menemukan permasalahan dengan bekerja secara kelompok. Hal ini sesuai dengan pendapat Ali (2008) menyatakan bahwa pembelajaran di lingkungan sekolah pada pembelajaran biologi menjadikan siswa memupuk kreativitas, kemandirian, kerjasama atau gotong royong dan meningkatkan minat siswa.

Berdasarkan tabel 3. dapat diketahui bahwa aspek ketuntasan belajar siklus 1 sebesar $82,35 \%$ dan siklus II sebesar 88,23\%. Peningkatan hasil belajar kognitif siswa ini terjadi karena siswa dengan pembelajaran di lingkungan sekolah memiliki pemahaman konsep sehingga siswa dapat menjawab pertanyaan dalam test dengan baik dan benar. Menurut Wibowo (2010) pembelajaran di lingkungan sekolah merupakan satu cara bagaimana kita meningkatkan kapasitas belajar siswa. Siswa dapat belajar secara lebih mendalam melalui objek-objek yang dihadapi dari pada jika belajar di dalam kelas yang memiliki banyak keterbatasan. Pembelajaran di luar ruangan lebih menantang bagi siswa dan menjembatani antara teori di dalam buku dan kenyataan yang ada di lapangan, sehingga dapat memproses konsep yang diterimanya dengan baik.

\section{Ranah Afektif}

Ranah afektif diukur untuk mengetahui sejauh mana sikap dan moral siswa yang dibentuk selama proses pembelajaran. Guru memberikan tes hasil belajar afektif pada setiap akhir siklus setelah dilaksanakan tes belajar kognitif. Tes belajar afektif terdiri dari 


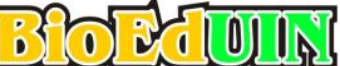

Jurnal Program Studi Pendidikan Biologi

20 soal, yaitu 10 pertanyaan positif dan 10 pertanyaan negatif. Bobot untuk pertanyaan positif secara berurutan, yaitu 5, 4, 3, 2, dan 1 sedangkan untuk pertanyaan negatif secara berurutan, yaitu 1, 2, 3, 4, dan 5. Menurut dalam suatu kegiatan, siswa tidak hanya menghadiri kegiatan tetapi juga bereaksi terhadap sesuatu, penilaian menghargai peranan ilmu pengetahuan dalam kehidupan. Dalam penelitian ini, hasil belajar afektif siswa diperoleh dari hasil test sikap skala Linkert. Secara klasikal ketuntasan hasil belajar ranah afektif siswa mengalami peningkatan dari siklus I ke siklus II. Pada siklus I rata-rata ketuntasan belajar afektif adalah sebesar $82,29 \%$ dan meningkat menjadi $85,02 \%$ pada siklus II. Hal ini menunjukkan terjadi peningkatan sebesar $2,73 \%$. Peningkatan tersebut dikarenakan siswa sudah mulai terbiasa dengan menggunakan pembelajaran di Luar Ruangan. Penerapan pembelajaran di lingkungan sekolah mampu meningkatkan hasil belajar siswa. Adanya kolaborasi siswa dalam kelompok belajar secara heterogen mampu memberikan saling ketergantungan yang positif antar siswa. Pada kegiatan kelompok ini memberikan kesempatan kepada siswa untuk mengamati masalah yang ada di lingkungan, berdiskusi, bertukar ide dan saling berbagi pengetahuan. Peningkatan yang terjadi pada siklus II disebabkan karena meningkatnya motivasi belajar siswa.

\section{KESIMPULAN}

Berdasarkan paparan data dan pembahasan tentang penerapan pembelajaran di lingkungan sekolah dapat disimpulkan bahwa keterlaksanaan pembelajaran mengalami peningkatan sebesar 8,3\% dari siklus I sebesar 91,7\% meningkat menjadi100\% pada siklus II. Penerapan pembelajaran di lingkungan sekolah dapat meningkatkan motivasi belajar biologi siswa kelas X-MIA sebesar 11,26\%. Motivasi belajar siswa pada siklus I 72,24\% meningkat $85,50 \%$ pada siklus II. Penerapan model pembelajaran di lingkungan sekolah dapat meningkatkan hasil belajar biologi siswa
p-ISSN : 2338-7173

e-ISSN : 2615-0417

(Februari), Vol. (8), No.(1)

Arikunto (2009) ranah afektif meliputi penerimaan yaitu kesediaan siswa untuk memperhatikan, mendengarkan dengan sungguh-sungguh, menunjukkan kesdaran akan pentingnya belajar, partisipasi aktif kelas X-MIA sebesar 2,94\%. Peningkatan hasil belajar ranah kognitif siswa pada siklus I $82,35 \%$ menjadi $88,23 \%$ pada siklus II sedangkan hasil belajar ranah afektif siswa pada siklus I $82,29 \%$ menjadi $85,15 \%$ pada siklus II.

\section{SARAN}

Berdasarkan hasil penelitian dapat dikemukakan saran bagi guru bidang studi Biologi untuk menerapkan pembelajaran di lingkungan sekolah agar tercipta suasana pembelajaran yang menarik bagi siswa serta tidak membosankan. Guru harus memperhatikan alokasi waktu, Kompetensi Dasar (KD) yang digunakan, dan sumber belajar yang tersedia sehingga pembelajaran di lingkungan sekolah terlaksana dengan baik.

\section{DAFTAR PUSTAKA}

Arikunto, S. 2009. Dasar-dasar Evaluasi Pendidikan. Jakarta : Bumi Aksara.

Ali, H. 2008. Efektifitas Pembelajaran Biologi Melalui Metode Out Door Study. Biomature Vol 8 (1): Hal 18-23 April 2008 (Online). (http://isjd.pdii.lipi.go.id/admin/jurnal/9 1091823.pdf, diakses tanggal 27 Januari 2012).

Djamarah, S. B dan Aswan Z. 2006. Strategi Belajar Mengajar. Jakarta: Rineka Cipta.

Susanto, P. 2002. Keterampilan Dasar Mengajar IPA Berbasis Kontruktifisme. Malang: Universitas Negeri Malang.

Uno, H. 2007. Teori Motivasi dan Pengukurannya. Jakarta: Bumi Aksara

Wibowo, Y. 2010. Bentuk-bentuk Pembelajaran Outdoor. (Online). (http://staff.uny.ac.id/sites/default/files/t mp/Bentuk\%20pembelajaran\%20outdo or.pdf, diakses tanggal 3 Juli 2018). 